\title{
NAQLI KNOWLEDGE COURSE-BASED: AN OVERVIEW OF STUDENTS' PERCEPTION
}

\author{
Azniwati Abdul Aziz ${ }^{1}$, Mohamed Akhiruddin Ibrahim ${ }^{2 \star}$, Wan Amir Nudin Wan Ishak ${ }^{1}$, \\ Sanusi Shariff ${ }^{1}$, Rasmina Hasbullah ${ }^{1}$ and Irwan Mohd Subri ${ }^{3}$ \\ ${ }^{1}$ Tamhidi Centre, Universiti Sains Islam Malaysia, MALAYSIA, \\ ${ }^{2}$ Dr., Faculty of Quranic and Sunnah Studies, Universiti Sains Islam Malaysia, MALAYSIA, \\ akhiruddin@usim.edu.my \\ ${ }^{3}$ Assoc. Prof, Dr., Faculty of Shariah and Law, Universiti Sains Islam Malaysia, MALAYSIA \\ ${ }^{*}$ Corresponding author
}

\begin{abstract}
This research analyses Al-Mabadik Al-Fiqhiyyah (Principles of Islamic Jurisprudence) as one of a compulsory course that should be taken by the students from Tamhidi of Shariah and Law students in Universiti Sains Islam Malaysia (USIM). Thus, this research aims to discover students' perception regarding this course, including the level of difficulty of the content. Besides, this research also aims to study on how far this subject benefit the students especially when it comes to contemporary issues in order to ensure the effectiveness of teaching and learning process. This study also revealed their ability to differentiate with the other course that should be taken during first semester as well, which is Al-Madkhal ila al-Syari'ah and the relationship with other disciplines. They might have quite similar perception towards this course since they have been exposed to this field since their secondary school. The observation concludes that generally the students are able to understand the content of the course, relate it with contemporary issues and aware that this course indirectly connected with three main figh branches: Fiqh, Usul Al-Figh and Al-Qawa'id AlFiqhiyyah. This course also provides basic knowledge of Islamic Law, fiqh terminology as well as skills required in Islamic legal system as their preparation to further their Bachelor studies in Faculty of Shariah and Law The course required students to complete 4 credit hours for the whole semester as one of the conditions. In line with USIM's principle which is the integration of Naqli and Aqli knowledge, this study found the importance of this concept for the development of education, institution and faculty, as well as widen the scope of the prescribed courses. Furthermore, education is one of the processes for country development by producing citizens with high level of intellectuality and can contribute for the better nation especially through universities' curriculum. The result from this study will be a benchmark for Tamhidi Centre to continue and do some improvement in teaching and learning process without leaving behind the concept of the integration of Naqli and Aqli knowledge.
\end{abstract}

Keywords: Perception, Al-Mabadik Al-Fiqhiyyah, curriculum, Naqli knowledge 


\section{INTRODUCTION}

Allah has created man with one purpose which is to worship Him as the only Almighty God in this world. That is why He has constantly sent Messengers and Prophets to guide human being and convey messages about Islam as a religion which comprehensive to all aspects of life (Mustapha, 1978). Meaning that all human behaviours are bounded to Islamic rulings (shariah) anytime and anywhere and the rules is not changeable until the Day of Judgement because Allah has created the rules according to human needs and based on reality.

Fiqh (Islamic Jurisprudence) is almost similar to Islamic law itself. It has a big role in regulating human life not just as individuals, but also as part of the society and in their relation with God. According to Shoayb Ahmed (2005), fiqh consist of the laws that control a Muslim daily life and then the Prophet Muhammad explained and practically demonstrates the law. Therefore, the topics in figh are very wide for example the topics regarding to taharah (purification), prayer, the funeral prayer, zakah (the poor tax), fasting, hajj (the pilgrimage), trade, inheritance, marriage, divorce and justice as written in Al-Fiqh Al-Manhaji 'ala Madhhab Al-Imam Al-Syafi'i (Al-Khin, 1992).

This field of study is available in USIM under Faculty of Shariah and Law for Bachelor students. This faculty aims to introduce the integration of two areas of law in its programme, which is shariah and civil law (Retrieved from http://fsu.usim.edu.my/en/info-usim/the-faculty). However, before enrolling in bachelor, the students need to finish their foundation for one year through Tamhidi of Shariah and Law programme that provided by the university.

Tamhidi is a programme for SPM graduate which aims to prepare candidates for the First Degree level. Tamhidi is derives from one of Arabic word which means 'preparation' such as the term 'Matriculation' in the Ministry of Education and International Islamic Universiti Malaysia, 'Foundation' in Universiti Malaya, 'Foundation Year' in University Teknologi Malaysia or similar to pre-university programme (STPM, HSC or A' Level). Thus, Tamhidi programme is equivalent to 'foundation' programme run by universities that have been listed (Ibrahim, 2016).

To complete their Tamhidi, there is one compulsory subject that need to be taken by students on their first semester of Tamhidi which is Al-Mabadik Al-Fiqhiyyah course. This course contain two sections. First is Usul Al-Fiqh which explain Islamic law sources and the method to understand the source as well as the technique to discover the law through the Quran and the Sunnah. Secondly is Al-Qawa'id Al-Fiqhiyyah which explain fiqh methodology or Islamic legal maxims to understand the nature of shariah easily.

However, the university discover some problems within that course which is some of the students could not identify the element of Naqli in Al-Mabadik Al-Fiqhiyyah course and leave several question mark about their perception and level of understanding regarding that particular course.

Therefore, this study is prepared to know perception of students from Tamhidi of Shariah and Law regarding this course to observe the significance of this subject towards students through teaching and learning process because it is important for them to master in this field of knowledge since this is what they are specialised in. At the same time, this study reveal their ability to solve contemporary figh issues by using the integration of Naqli and Aqli knowledge in order respond to the university holistic approach towards the delivery of knowledge.

\section{RESEARCH METHODOLOGY}

A pilot study was conducted in the first place to discover perception of students from Tamhidi of Shariah and Law regarding Al-Mabadik Al-Fiqhiyyah course. Hence, it shows that there is no significant differences between the pilot study and the real study.

Pilot study is a small scale preliminary study or an experiment conducted as a preparation for the main study (Polit et. al., 2001). According to Edwin R. \& Vanora (2001), one of the advantages of conducting pilot study is it could give earlier warning about the probability of the real experiment to fail, or the protocol could not be followed, or the methodology suggested or the instrument is not suitable or too difficult. The study utilized quantitative research by survey method. Bhawna \& Gobind (2015) alleged that quantitative research is a methodical study of observable circumstances via statistical, mathematical, or computational techniques. It is focus on survey and experiment, as it build upon hypothesis or existing theories (Leedy \& Ormrod, 2001). It also creates meaning through objectivity uncovered in the collected data (Williams, C., 2007).

According to Mathers, N. et.al, (2009), there are three main methods of collecting survey data which are face-to-face interviews, telephone interviews and questionnaires. He claimed that this method is cheaper and quicker compared to personal interviewing if the sample is large and widely distributed. Thus, this 
research use a questionnaire form in order to gather data which involve all 114 students from Tamhidi of Shariah and Law of USIM as samples to measure their perception towards Al-Mabadik Al-Fiqhiyyah course which is one of compulsory subject during their Tamhidi level. So the sample of this research is not chosen randomly but specifically to students from Tamhidi of Shariah and Law of USIM without involving other students from other faculties.

Questionnaire design is very important to make sure all the respondents understand the questions and can answer it precisely. Thomas, F. B., (2001) stated that there are three elements in designing questionnaire: determine the questions to be asked, choose the question type for each question and specify the wording and design the question sequence and overall questionnaire result.

Thus, the questionnaire contain two sections, which is Section A and Section B. Section A is related to background information of respondents, which are their gender, types of former secondary school, their knowledge about figh knowledge, from where they gained that knowledge and to which extent is their interest towards that subject and finally their performance in that subject during their first semester of Tamhidi. While Section B require respondents to answer 6 questions (B1, B2, B3, B4, B5, B6) related to their perception towards Al-Mabadik Al-Fiqhiyyah course based on Five Likert Scale which is Strongly Disagree (1), Disagree (2), Not Sure (3), Agree (4) and Strongly Agree (5). This attitudinal scales was created by Likert because of the difficulty of measuring character and personality traits then the data analysed based on the composite score (Harry N. B. \& Deborah A. B., 2012). Hence, this B section intend to investigate students' thought towards Al-Mabadik Al-Fiqhiyyah course that has been learned throughout their first semester of Tamhidi.

The first question asked was about the level of difficulty regarding to the content of Al-Mabadik Al-Fiqhiyyah course. This question aims to know whether they understand the subject matter or not because the content of this subject maybe related to what they have learned during their secondary school. Meanwhile the second question is related to the acquisition of broader knowledge through Al-Mabadik al-Fiqhiyyah course which aims to know to which extent this course can give benefit to them. Then they were asked about their capability to relate the content of the course with current issues and their understanding and explanation towards any raised issues throughout Al-Mabadik Al-Fiqhiyyah course. The next question was regarding to the content of Al-Mabadik Al-Fiqhiyyah course and Al-Madkhal ila Al-Shariah course to make sure that they can differentiate between those two courses. And the last question asked was about relationship between $A /-$ Mabadik al-Fiqhiyyah course and the three main discipline of fiqh which are Fiqh, Usul al-Figh and AlQawaid al-Fiqhiyyah. Thus, all answers of these six questions answered by the respondents will be analysed in this study.

\section{RESEARCH FINDINGS AND DISCUSSIONS}

The most important factor of implementation is deep understanding. Arief \& Salmiah (2010) stated that objective of learning fiqh knowledge is because it is part of the Islamic law that should be learned by all individual Muslim, so that it could be understood and implemented right away according to Allah's will and His Messenger. Moreover, the nature of the development of fiqh knowledge itself is in line with the development of society norms. Thus, this kind of knowledge is very important to make sure people stay away from taqlid or follow shariah law without knowing the reason. Those who learn and study in depth the knowledge of fiqh is more pious because they are always be cautious with halal and haram (Abu Habib, 1997). Therefore, it is no point to keep delivering the content of Al-Mabadik Al-Fiqhiyyah course if students of Tamhidi from Faculty of Shariah and Law could not understand about the subject matter.

So, the first item (B1) asked is about the level of difficulty regarding to the content of Al-Mabadik AlFiqhiyyah course as referred to the table below:

Table 1: The percentage of students who are agree that the content of Al-Mabadik Al-Fiqhiyyah course is difficult to understand.

\begin{tabular}{|c|c|c|c|c|c|}
\hline \multicolumn{2}{|c|}{} & & & & \\
\hline \multirow{4}{*}{} & Frequency & Percent & Valid Percent & Cumulative Percent \\
\cline { 2 - 5 } & Strongly Disagree & 1 & 0.9 & 0.9 & 0.9 \\
\cline { 2 - 5 } & Disagree & 18 & 15.8 & 15.8 & 16.7 \\
\cline { 2 - 5 } & Not Sure & 21 & 18.4 & 18.4 & 35.1 \\
\cline { 2 - 5 } & Agree & 50 & 43.9 & 43.9 & 78.9 \\
\cline { 2 - 5 } & Strongly Agree & 24 & 21.1 & 21.1 & 100.0 \\
\hline
\end{tabular}


Table 1 clearly shows negative feedback since more than half of the respondents chose "strongly agree" and "agree" with total of $24(21.1 \%)$ and $50(43.9 \%)$ out of 114 students. Meaning that majority of them found that the content of Al-Mabadik Al-Fiqhiyyah course is difficult to understand. While 21 (18.4\%) students "not sure" about the level of difficulty regarding to the content of that course. There is a probability that they found some of the topics were easy to understand and some topics were quite difficult to understand. Unfortunately only $18(15.8 \%)$ of 114 students chose "disagree" with that statement, which means it is not difficult for them to understand the content of Al-Mabadik Al-Fiqhiyyah course. Only one (0.9\%) of the respondents confident with his or her perception towards the content of that course which is easy to understand since he or she answered "strongly disagree".

The huge gap between those who are agree and disagree yielded that many students of Tamhidi of Shariah and Law found that the content of this course is difficult to understand. The faculty or the person in charge with students' academic affair should re-examine the subject and do some modification about the content, so that all students could understand about the subject matter easily through teaching and learning process.

Even so, this subject contains basic knowledge of Islamic Law and figh terms that they have learned during their secondary school through some subjects such as Islamic Education, Quran \& Sunnah Education and Shariah Education. This course might be difficult to understand but this does not necessarily mean it could not be understood forever because students may need some time to do revisions and consult with lecturer about the subject to clarify the topics that require more explanation. After that, the students will be able to understand that knowledge as they are capable to practice what they have learned because education in Islam is not just about acquiring intellectual knowledge but it is a means of moulding the nature and character of individuals, so that they can represent Islamic values, behave like vicegerent of Allah in this world (Firdaus \& Shah, 2013). Hence, at the end of teaching and learning process of Al-Mabadik AlFiqhiyyah course, students are not merely expected to achieve success on paper because of memorizing the whole thing but it is all about understanding the content, so that it can be implemented in their life in order to strengthen relationship between man and the Creator.

Therefore, the second item (B2) asked was concerning acquisition of broader knowledge through AlMabadik al-Fiqhiyyah course:

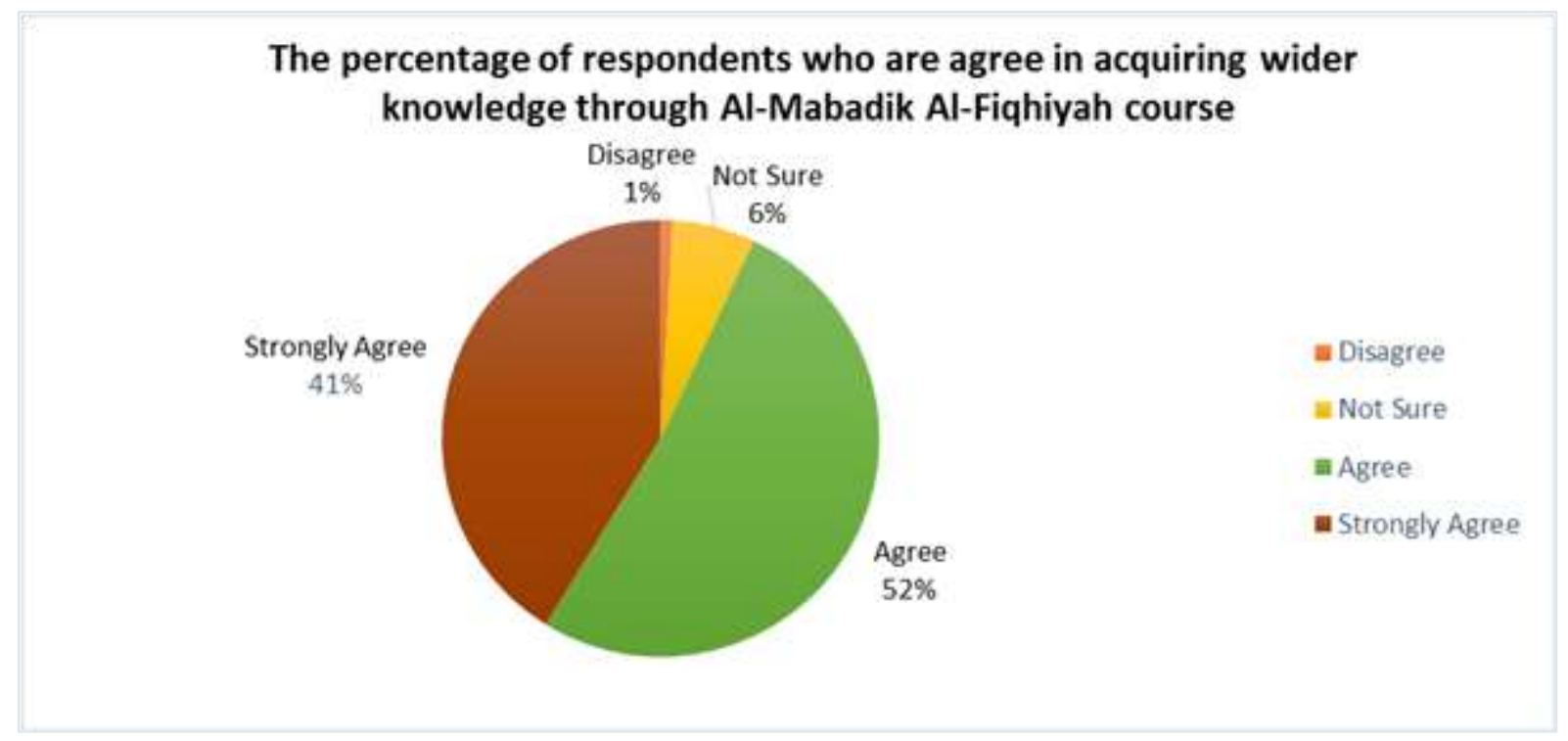

Pie Chart 1: The percentage of respondents who are agreeing in acquiring wider knowledge through AlMabadik Al-Fiqhiyyah course.

Tamhidi students are upcoming delegates that will turn on the spirit of fiqh knowledge and practice what they have learned. Since they will learn deeper knowledge about this subject matter during bachelor degree in the future, it is a necessary to master this course properly during their Tamhidi level.

The analysis yielded good reaction from respondents since $41 \%$ of them chose "strongly agree" while $52 \%$ chose "agree", which conclude positive results since majority of them concur about acquisition of wider knowledge through Al-Mabadik Al-Fiqhiyyah course. Moreover, no one chose "strongly disagree" and just $1 \%$ chose "disagree" shows that only few students have a thought that they were not gained wider knowledge through Al-Mabadik Al-Fiqhiyyah course, probably consist of those who are not understand the 
contents and the topics that they have learned in class. It proved that the students' perception towards this course is that this course can increase their knowledge of fiqh.

There was a contradict results between first and second questions because a lot of students said this course is difficult to understand but no one said that they are not getting wider knowledge through this course. It is probably because at first they thought the content is difficult but then after go deeper and understand the knowledge, they realize that this course benefit them a lot.

Indeed, this course is related to everyday life, which specifies modes of worship, moral standards and principles of interpersonal relationship since fiqh is derived from the Quran, the Sunnah, the ijma' (the consensus) and the qiyas (deduction of analogy). When dogmatic and scholastic theology (al-kalam) combined with these four sources, it creates foundation for the science of shariah which means "the road" (Doi, 1981). Figh is defined as the knowledge of rights and duties as well as the basics of Islamic legal system (Etim, 2013) and has a connection with their field of study which is shariah and law.

That is why figh knowledge has to be in equivalent movement with contemporary issues. The attempt to contemporise figh is not recent circumstances because it has always been a part of fiqh evolution (Muhammad Hanif \& Sharifah Thuraiya S.A.A., 2011). For example the contemporary issue in zakat- an act of monetary worship from Muslims who possessed specific amount of wealth, has to give away the prescribed rate to specifically designated categories of people (Wahbah, Z., 1989) such as the criterion of zakatibility, legal-threshold for zakat, the ratio of zakat and many more (Mek Wok \& Sayyed, 2008).

Therefore, this study will reveal students' perception concerning to which extent Al-Mabadik Al-Fiqhiyyah course assist them in relating it with contemporary issues, which is the third item (B3) asked in this study. Based on the feedback, it can be considered as positive result since neither of them chose "strongly disagree" nor "disagree", which means most of the students have a thought that they can relate Al-Mabadik Al-Fiqhiyyah course with contemporary issues with the total of $99(86.1 \%)$ out of 114 students chose "strongly agree" and "agree", while the rest (13.2\%) answered "not sure". This is probably because they are not fully understand about the content of the course. However, this outcome achieve encouraging results because when the students can relate the course with any of the contemporary issues, automatically they understand what they have learned in class.

The contemporary figh is a necessity among Muslim because new problems will continue to arise and need new solutions. Without contemporary figh, mercy to the entire universe will not be realised because it does not fulfil the characteristics of Islam which is comprehensive. Moreover, difficulties and injustice will happen if Muslim did not implementing figh according to current realities (Muhammad Hanif \& Sharifah Thuraiya S.A.A., 2011).

This contemporary issues might develop jurisprudential disagreement among mujtahid - the one who perform ijtihad, which means an attempt to choose within the content of the Quran and the Sunnah between two or more interpretations to conclude any new hukm (rulings) in order to address new legal situations (AlQadri, 1950) and create confusing idea among those who had no capability to learn figh knowledge.

Thus, the fourth item (B4) analysed in this study was about their ability to understand and explain any raised issues through Al-Mabadik Al-Fiqhiyyah course. As mentioned before, those issues can cause differences in opinion. This is because human is a homo conflictus creations, which usually involved in disagreement, contradiction and competition of idea or physical, whether voluntarily or forced.

On the other hand, Tyler (2010) claimed that the effectiveness of teaching and learning process can be measured by student-performance data, classroom observation, feedback from students, and so on, to provide well-rounded and well-founded input into important decisions. This includes using the raised issues and ask students to link it with Al-Mabadik Al-Fiqhiyyah course to test their understanding about that particular subject. Yet, the teaching and learning process does not guarantee their understanding of issues that have been discussed and solved.

It is proven by pie chart below, which shows the percentage of the respondents who agreed that they could understand and explain raised issues through Al-Mabadik Al-Fiqhiyyah course: 


\section{The percentage of respondents who are agree that they could understand and explain raised issues through Al-Mabadik Al-Fiqhiyah course}

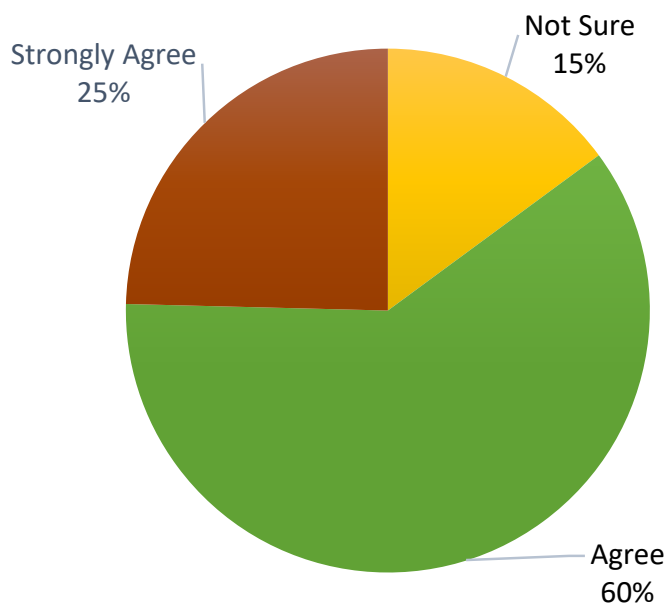

Pie Chart 2: The percentage of the respondents who agreed that they could understand and explain raised issues through Al-Mabadik Al-Fiqhiyyah course.

Referring to the pie chart above, it is obvious that majority $(60 \%)$ of the respondents "agree" with that statement. However, there are also some students answered "not sure" whether they could understand and explain raised issues through Al-Mabadik Al-Fiqhiyyah course or not, which is $15 \%$. These number of students probably came from those who could not relate the content or topics learned throughout this course with contemporary issues as mentioned in the third item before. Meanwhile, those who are confident with their perception regarding this statement chose "strongly agree", which is quarter percentage $(25 \%)$ of the respondents. It can be concluded that this result shows positive thought among students since almost all of them agreed that they could understand and explain raised issues through Al-Mabadik Al-Fiqhiyyah course.

In fact, there is another course that seems similar to Al-Mabadik Al-Fiqhiyyah course which is Al-Madkhal ila Al-Shariah (Introduction to Shariah), but actually those two compulsory-to-take subjects are different to each other and it is important to Muslims to know that. Both of the subjects were taught to students on semester 1 of Tamhidi Shariah and Law with 4 credit hours (Sabri et. al, 2015).

Abdul Karim Zaidan (2001) said in his book Introduction to Islamic Shariah, that Shariah is related to legal provisions concerning doctrine (aqidah) or ethics (akhlak) or worship (ibadah) or transaction (muamalat), while figh is a practical provisions, which is the rules (ahkam) of worship and transaction. So, shariah has broader meaning than figh since fiqh only focus on practical rulings while shariah embrace all rulings.

Shariah also has been defined as a discussion on the duties of Muslim (Gibb, 1970) because all deeds of Muslims are adhere to the rules set by God from two main sources which is the Quran and the Sunnah. It has the same meaning to the term ad-deen (religion) because the subject to be reached by both of them is God, and deen is the submission to follow the path and the subject is human being (Rahman, 1979).

Therefore, this study discovered perception of 114 students from Tamhidi Shariah and Law towards their ability to differentiate between two courses, which are Al-Mabadik Al-Fiqhiyyah and Al-Madkhal ila Al-Shariah as the fifth item (B5). The table below shows the percentage of respondents who agreed that the content of Al-Mabadik Al-Fiqhiyyah course same with Al-Madkhal ila Al-Shariah course: 
Table 2: The percentages of respondents who are agree that the content of Al-Mabadik Al-Fiqhiyyah course same with Al-Madkhal ila Al-Shariah course.

\begin{tabular}{|l|c|c|c|c|}
\hline & Frequency & Percent & $\begin{array}{c}\text { Valid } \\
\text { Percent }\end{array}$ & $\begin{array}{c}\text { Cumulativ } \\
\text { e Percent }\end{array}$ \\
\hline Strongly Disagree & 4 & 3.5 & 3.5 & 3.5 \\
\hline Disagree & 34 & 29.8 & 29.8 & 33.3 \\
\hline Not Sure & 37 & 32.5 & 32.5 & 65.8 \\
\hline Agree & 32 & 28.1 & 28.1 & 93.9 \\
\hline Strongly Agree & 7 & 6.1 & 6.1 & 100.0 \\
\hline Total & 114 & 100.0 & 100.0 & \\
\hline
\end{tabular}

The purpose of this question asked is to reveal their understanding towards both of the subjects. The analysis yielded that all students have a different perception regarding this matter. The highest percentage (37.5\%) goes to those who are "not sure" whether the content of Al-Mabadik Al-Fiqhiyyah course same with Al-Madkhal ila Al-Shariah course or not which is 37 out of 114 students. They could not determine the similarities and differences between the two subjects. The total of those who are agree and disagree is quite similar. $3.5 \%$ of the respondents chose "strongly disagree" while $29.8 \%$ chose "disagree, meaning that they can differentiate the content of both courses. On the other hand, $6.1 \%$ of the respondents "strongly agree" and $28.1 \%$ "agree" with that statement. They might understand both of the subjects through teaching and learning process but could not distinguish between the two courses.

According to Imam (2011), the difference between shariah and figh is the topic discussed in shariah is wider while the topic discussed in figh is limited to human action that can be classifies into following types: fard (obligatory), mustahab (recommended), mubah (neutral), makruh (discouraged) and haram (forbidden) (Chris \& Peter, 1991). It is also stated in Al-Ghazali (1993) book which is al-Mustasfa. Thus, it is clear that figh is the part of shariah. Moreover, figh issue a subject to change according to place, situation and reality. It is not going to end until the Day of Judgement because contemporary issue is in the need of ijtihad and not written directly in the Quran and the Sunnah (Al-Qadri, 1950).

That is why figh is not narrow subject. Ahmad Sarwat (2011) has classified figh in three main theme. The first category is fundamental category such as fiqh of ritual purity, fiqh of salah, figh of zakat, fiqh of fasting and figh of pilgrimage (haj), while the second category is for Islamic development category such as figh of munakahat (marriage), figh of muamalah (transaction), figh of mawarith (inheritance) and so on. The last category is called defensive category such as figh of jinayat (criminal). Thus, it is clear that there is many topics discussed in just one discipline of knowledge.

Other than fiqh itself, there is also another knowledge that has strong connection with fiqh which is Usul alFiqh (principles of Islamic Jurisprudence) and Al-Qawa'id al-Fiqhiyyah (legal maxims of Islamic Jurisprudence). Usul al-Figh can be defined as a framework of principles formulised in order to understand the rulings derived from shariah in everyday life (As-Shashi, 2014), while Al-Qawa'id Al-Fiqhiyyah can be defined as theoretical generalizations, usually in the form of short descriptions to express goals and objectives of the shariah (Kamali, 1998). Intisar Rabb (2010) noted that hey also play a role to enable fiqh to actively survive and keep helping to provide proper solutions in confronting contemporary legal issues.

These three subjects are essentials in understanding Islamic rulings among students especially for the students of Tamhidi of Shariah and Law because all their courses during Tamhidi level are related with those subjects. Therefore, this research will observe students' perception about Al-Mabadik Al-Fiqhiyyah course and the relation between fiqh, usul al-figh and Al-Qawa'id Al-Fiqhiyyah as the last item (B6) studied through this research.

The analysis shows that majority of them chose "strongly agree" (39.5\%) and "agree" (54.4\%). Those who chose these two answers might have strong reasons such as they understand the content of the course and they know that fiqh branches are very wide range. While the minority chose "not sure" (6.1\%), meaning that they were confuse whether those three subjects related to Al-Mabadik Al-Fiqhiyyah course or not. To summarize, this result can be concluded as positive result because almost all of them agreed that Al- 
Mabadik Al-Fiqhiyyah course related with those three main field of fiqh knowledge which are figh, usul al-fiqh and Al-Qawa'id Al-Fiqhiyyah. Next, a crosstab is set up to observe the correlation within the data analysed.

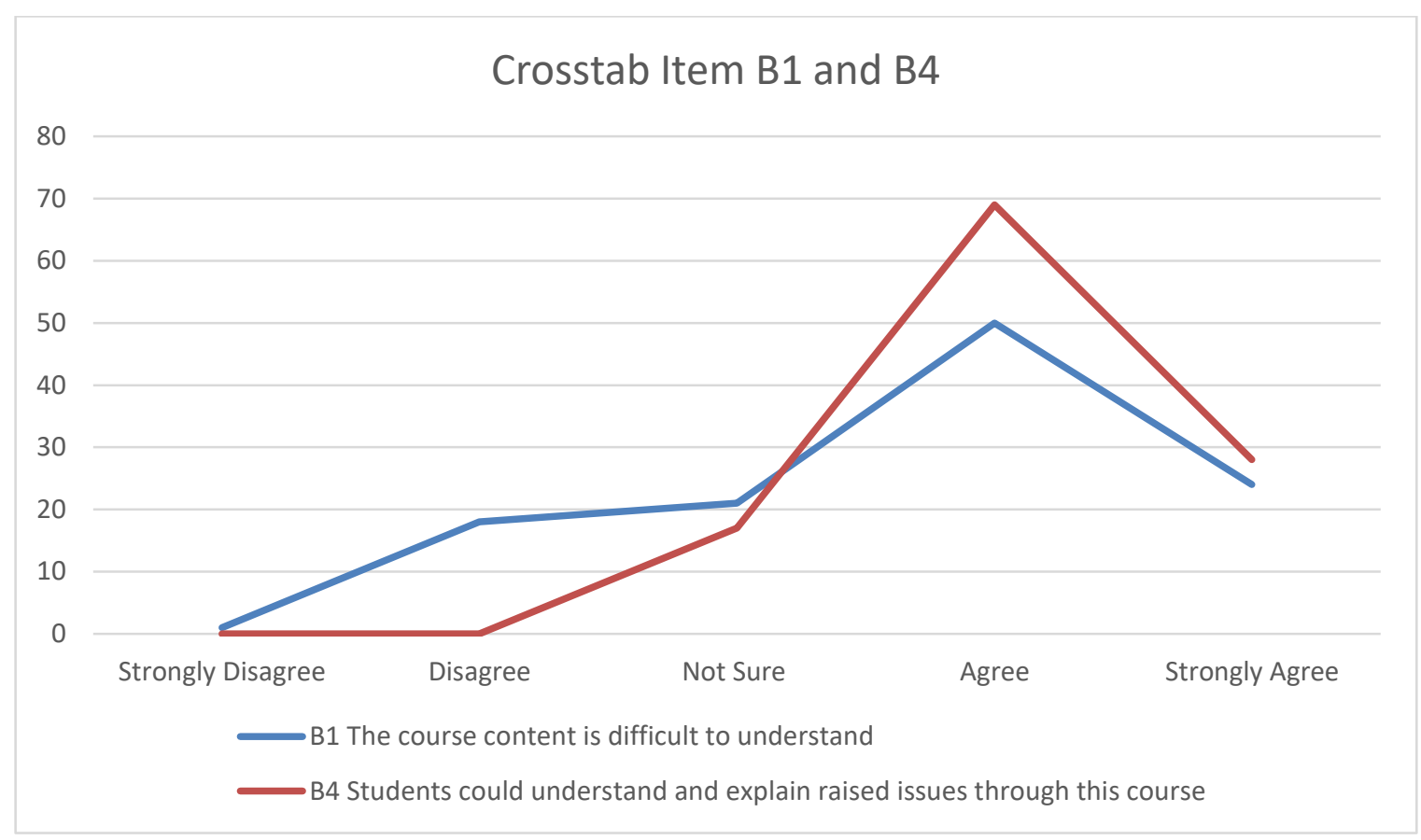

Line Chart 1: Crosstabs Item B1 and B4

Line Chart 1 demonstrates a crosstabs between Item B1 (The course content is difficult to understand) and Item B4 (students could understand and explain raised issues through this course). There are 50 respondents who are "agree" with Item B1. At the same time, those who are "agree" with Item B4 are 69 students. Research concluded that some of the students could not understand the question given properly and did not earnestly give the feedback. Therefore, this perception will be put out of the way and will not be counted in this section. Yet no doubt that the sudden increasing percentage also shows that some of the respondents did not have fixed perception about this issue. This is because there are students that are still confused about the chosen answer. Item B1 and B4 should have parallel result since both of the questions are related with each other. It is impossible to say that the course is difficult to understand but at the same time the students could understand and explain raised issue based on what they have learned through this course. It is obvious that the difficult content of Al-Mabadik Al-Fiqhiyyah course can be a burden to students in understanding certain issues.

\section{CONCLUSION}

The successfulness of teaching and learning process is proved by the students' level of understanding, their achievement and data-performance towards the subject content. It is important to make sure the students obtained the message through curriculum prescribed by the university together with holistic approach towards the delivery of knowledge which is integrating physical and spiritual aspects.

USIM is the only university in Malaysia that adopt Naqli and Aqli concept, not only in academic programmes but also in practised throughout university including administration and management levels. That is why the university is very concerned about the implementation of this concept in order to produce students with high level of intellectuality in academic performance as well as contributing to the society of Islamic tradition.

The findings reached the conclusion that the students from Tamhidi of Shariah and Law in USIM found that the content of Al-Mabadik Al-Fiqhiyyah course is quite difficult to understand since there is a huge gap between those who agree and not agree with the statement. Thus, the faculty should re-examine the content of the subject to make sure the message is conveyed successfully through the course. However, majority of the students claimed to get wider knowledge through this course and no one answered strongly disagree with this statement, shows contradiction between those two statements. However, this research concluded that students found the course difficult to understand but after some time, they could understand and obtained wider knowledge through this course.

Moreover, no one claimed that this course did not help in relating the subject content with contemporary issues and majority of them could understand and explained raised issues through this course, which can be 
concluded as positive results. Since there was another course which seems similar with Al-Mabadik AlFiqhiyyah which is Al-Madkhal ila Al-Syariah, this research discovered that majority of the students are not sure the difference between those two courses but the good thing is majority of the students know about the relationship between Al-Mabadik Al-Fiqhiyyah course and three main main fiqh branches which is Fiqh, Usul al-Fiqh and Al-Qawa'id Al-Fiqhiyyah.

Certainly, the result indicated that Al-Mabadik Al-Fiqhiyyah course give a lot benefit to students since it is a basic knowledge of Islamic law, including fiqh, Usul al-Fiqh and Al-Qawa'id Al-Fiqhiyyah, which is their field of study. The course syllabus should be continued developed in the future because the content and explanation might be new input to the students. The teaching and learning process for this subject is very suitable for students to get clear overview regarding to contemporary raised issues and how does it connected with this course through learning process. This is because referring to the students' achievement in the past examination of Al-Mabadik Al-Fiqhiyyah course, majority of the students got A for that subject and only few of them got $C$ - and $D$. The result is still at the satisfactory level but still need improvement in the future.

Given the findings and conclusions, the study suggested that the contemporary raised issues that occurring in everyday life should be discussed more in class through teaching and learning process, so that the students are more exposed to the reality instead of theory and facts that written in the book. For example, the lecturer can ask the students to present any contemporary issues that related to topic discussed on that time as an assessment. This kind of activity is one of the effective way to make sure that all students understand the whole subject and obtain wider knowledge through that course.

It is hoped that this analysis towards Al-Mabadik Al-Fiqhiyyah course get positive reaction among the students of Tamhidi of Shariah and Law and can give benefit to the university especially within Tamhidi centre to make some improvement in order to increase the quality of education system in USIM through their curriculum.

\section{ACKNOWLEDGEMENTS}

The researchers would like to acknowledge Research Management Centre, Universiti Sains Islam Malaysia (USIM) for the financial support as this research was a part of its Grant (PPP/USG-0115/FPQS/30/11415) and (PPP-TAMHIDI-17115-00).

\section{REFERENCE LIST}

Ahmad Sarwat. (2011). Seri Fiqih Kehidupan (1): Ilmu Fiqih. Jakarta: DU Publishing.

Al-Ghazali, Abu Hamid Muhammad. (1993). Al-Mustasfa. Dar al-Kutub al-Ilmiah.

Al-Khin, Mustofa. (1992). Al-Fiqh Al-Manhaji 'ala Madhhab Al-Imam Al-Syafi'i. Damsyik: Dar Al-Kalam li AtTob'ah wa Al-Nashar wa Al-Tauzi'.

Al-Qadri, Muhammad Abdul Aleem Siddiqui. (1950). ljtihad and Mujtahid. The Codification of Islamic Law. Trinidad: Haji Mohammed Ibrahim.

Arief Salleh Rosman \& Salmiah Mohd Jupri. (2010). Kepentingan Mempelajari Dan Menguasai IImu Fikah Menurut Al-Hafiz Al-Khatib Al-Baghdadi Dalam Kitab Al-Faqih Wa Al-Mutafaqqih. UTM: Universiti Teknologi Malaysia Institutional Repository, 4.

As-Shashi, Imam Nidham Ad-din. (2014). Introduction to Usul Al-Figh According to Hanafi School, an adapted on the Usul As-Shashi by Abdul Aleem. United Kingdom, London.

Bhawna \& Gobind. (2015). Research Methodology and Approaches. India: Punjab, Moga, Moga College of Education. Journal of Research \& Method in Education.

Chris, H. \& Peter, C. (1991). What is Islam? A Comprehensive Induction. Virgin Books, 46.

Doi, A.R.I. (1981). The Cardinal Principles of Islam. Zariah: Hudahuda.

Edwin R. Van Teijlingen \& Vanora Hundley. (2001). The Importance of Pilot Studies. http://sru.soc.surrey.ac.uk/SRU35.html

Etim, E. Okon. (2013). Islamic Jurisprudence and the Primacy of Shariah. Asian Economic and Social Society, International Journal of Asian Social Science, 3 (1), 138-149. 
Firdaus, F. Y. R. \& Shah J. M. (2013). Islamic Education: The Philosophy, Aim and Main Features. Int. J. Educ. Res., 1: 1-18.

Gibb, Hamilton Alexander Rosskeen. (1970). Mohammedanism: an Historical Survey. Oxford University Press, 68.

Habib, Sa'di Abu. (2006). Ensiklopedi ljmak. Jakarta: Pustaka Firdaus.

Harry, N. B. \& Deborah, N. B. (2012). Analysing Likert Data. West Virginia: West Virginia University Morgantown, Journal of Extension, 50(2), 1.

Ibrahim, M.A. (2016). The Integration Of Naqli Knowledge Of Science Courses In Institutions Of Higher Learning Foundation Centres: Study On Tamhidi Centre, Universiti Sains Islam Malaysia. Proceeding of ADVED 2016 2nd International Conference on Advances in Education and Social Sciences.10-12 October 2016- Istanbul, Turkey. 493-499.

Imam, Muhammad Kamal Ad-Din. (2011). Baina Al-Fiqh wa Al-Shariah. Cairo: Centre for Epistemological Studies.

Intisar Rabb. (2010). Islamic Legal Maxims as Substantive Canons of Construction: Hudud-Avoidance in Cases of Doubt, in: Islamic Law and Society, 63.

Kamali, Mohammad Hashim. (1998). Qawa'id Al-Fiqh: The Legal Maxims of Islamic Law. The Muslim Lawyer Journal. The Association of Muslim Lawyers. Volume 3. Issue 2.

Leedy, P. \& Ormrod, J. (2001). Practical Research: Planning and Design (7 ${ }^{\text {th }}$ ed.). Upper Saddle River, NJ: Merrill Prentice Hall. Thousand Oaks: SAGE Publications.

Mathers, N., Fox, N., Hunn, A. (2009). Surveys and Questionnaires. National Institute for Health Research: The NIHR Research design Service for the East Midlands.

Mek Wok, M. \& Sayyed Sikandar, S. H. (2008). Debatable Issues in Fiqh al-Zakat: A Jurisprudential Appraisal. International Islamic University Malaysia. Jurnal Fiqh: No 5.

Muhammad Haniff Hassan \& Sharifah Thuraiya S.A. Alhabshi. (2011). Contemporary Fiqh in Singapore: Some Observations. Islam and Civilization Renewal. Pluto Journals, ICR2-4 01.

Polit, D.F., Beck, C.T. \& Hungler, B.P. (2001). Essentials of Nursing Research: Methods, Appraisal and Utilization. $5^{\text {th }}$ Ed., Philadelphia: Lippincott Williams \& Wilkins (http://sru.soc.surrey.ac.uk/SRU35.html)

Mustapha, A. F. (1978). Islam a Comprehensive Way of Life. Australia: Melbourne.

Rahman, Fazlur. (1979). Islam. Chicago: University of Chicago Press.

Sabri, M.N.M, Aziz, A.A \& Ibrahim, M.A (2015), Sains Islam dan Pendidikan : Ke Arah Melahirkan Generasi Terbilang, Bangi : Darul Shakir

Shoayb Ahmed. (2005). The Development of Islamic Jurisprudence (Fiqh) and Reasons for Justice Disagreements Among Schools of Law. University of South Africa.

Thomas, F. B. (2001). A General Introduction to the Design of Questionnaires for Survey Research. University of Leeds: Information Systems Services, Guide to the Design of Questionnaires.

Tyler, L. (2010). Measuring Teaching Effectiveness.

Wahbah al-Zuhaili. (1989). Al-Fiqh Al-Islami wa Adillatuhu. Beirut: Dar al -Fikr (2), 730.

Williams, C. (2007). Research Methods. Grand Canyon University. Journal of Business \& Economic Research (5).

Zaidan, Abdul Karim. (2001). Introduction to Islamic Shariah. Alexander: Dar Umar bin Khatab.

http://www.edweek.org/ew/articles/2010/01/27/19tyler.h29.htm|

http://fsu.usim.edu.my/en/info-usim/the-faculty 